Grasz, S., T. Keisanen, F. Oloff, M. Rauniomaa, I. Rautiainen \& M. Siromaa (toim.) 2020. Menetelmällisiä käänteitä soveltavassa kielentutkimuksessa - Methodological Turns in Applied Language Studies. AFinLAn vuosikirja 2020. Suomen soveltavan kielitieteen yhdistyksen julkaisuja n:o 78. Jyväskylä. s. i-xvi.

\author{
Sabine Grasz, Tiina Keisanen, Florence Oloff, \\ Mirka Rauniomaa, lira Rautiainen \& Maarit Siromaa \\ University of Oulu
}

\title{
Methodological turns in applied language studies
}

The theme of the AFinLA 2020 Yearbook Methodological turns in applied language studies is discussed in this introductory article from three interrelated perspectives, variously addressed in the three plenary presentations at the AFinLA Autumn Symposium 2019 as well as in the thirteen contributions to the yearbook. In the first set of articles presented, the authors examine the role and impact of technological development on the study of multimodal digital and non-digital contexts and discourses and ensuing new methods. The second set of studies in the yearbook revisits issues of language proficiency, critically discussing relevant concepts and approaches. The third set of articles explores participation and participatory research approaches, reflecting on the roles of the researcher and the researched community.

Keywords: applied language studies, applied linguistics, methodology, research data, research methods

Asiasanat: metodologia, soveltava kielentutkimus, soveltava kielitiede, tutkimusaineistot, tutkimusmenetelmät 


\section{Introduction}

In the past decade especially, the increased diversity and accelerated digitalization of society has led to a multiplicity of views on language use, learning and communication. The recognition of these changes has brought about a demand, once again, to re-examine and redefine the methodological approaches within applied language studies. Applied linguists are increasingly engaged in finding new ways to address and solve real-life problems. In this process, ethical considerations and the pursuit of ecologically, economically and socially sustainable practices play a significant role. Participatory approaches, interventions, and other methodological and practical solutions are sought to answer the challenges of the contemporary world. The contributions to this yearbook, which are all based on presentations at the AFinLA Autumn Symposium 2019, put forward a selection of proposals for tackling the increasingly complex settings and questions that applied language studies currently deal with and thus complement recent methodological explorations in the field (see, e.g. Duff \& Byrnes 2019; Haapanen, Kääntä \& Lehti 2018).

During her plenary presentation Nexus Analysis as a framework for Social Media Studies at the symposium, Malene Charlotte Larsen (University of Aalborg) explored nexus analysis (Scollon \& Scollon 2004) as a suitable framework for studying online social interactions among young people. Larsen demonstrated that nexus analysis can be further developed and exploited for these new communication forms and spaces and, more specifically, for investigating how young people build up and maintain friendships and identities in online environments. Indeed, challenges such as the growing variety, quantity and complexity of different types of data and the way that on- and offline worlds are increasingly and intimately interconnected require applied linguists, among others, to reflect on the adequacy of previously developed methods and frameworks. These challenges will be further discussed in section 2 of this introductory article.

In his plenary presentation at the symposium as well as in his contribution to this yearbook, AFinLA chair Juha Jalkanen brings forth - referring to the topic of the symposium - that many of current societal problems are by nature multidimensional, so-called wicked problems. Wicked problems are complex, often ill-defined, interconnected and ever-changing, and solving them is not possible by single experts or disciplines (Irwin \& Kossoff 2020) but requires novel, multidisciplinary approaches. Applied linguists have been engaged in discovering methodological solutions to answer the multi-layered and complex language-related challenges in cooperation with experts from different fields. According to Jalkanen, many of these new methodological solutions move in border areas, and interaction between, for example, researchers, research participants, disciplines and society plays a key role. Jalkanen examines this by taking universities as an example and focuses both on the link between research and teaching and on the need for creating social relation- 
ships and interaction in research processes in order to solve (wicked) problems of everyday life.

Ray Wilkinson (University of Sheffield), the third plenary speaker at the symposium and an author of this yearbook, provides an example of how different fields of research in applied linguistics, in his case conversation-analytic research on atypical interaction, may identify challenges faced by participants in their everyday lives and thus provide a starting point for developing practical solutions to address these. By going beyond the analysis of individual communicative impairments - as most of the research in this field has done so far - Wilkinson's focus is on interaction of speakers with a combination of different disorders. This is an important addition to existing research because co-occurring disorders are quite common, for example, among stroke patients, and can cause not only more frequent and more problematic interactional trouble but may also have different kinds of impact on interaction. Wilkinson examines three episodes of interaction, in which aphasia co-occurs with dysarthria, dyspraxia or executive function deficits, concentrating on problems in understandability that lead to other-initiated repair. Focusing on only one feature in the interaction of speakers with different combinations of disorders allows Wilkinson a comparison between them. The analysis shows that all three episodes have something in common: the difficulty of the recipient to grasp the trouble source and the prolonged repair activity. Both seem to be linked to the co-occurrence of communicative disorders. All in all, the model of analysis offers a comparative approach with a strong empirical foundation, and it allows for a more profound and multifaceted understanding of the specific interactional challenges that emerge with various disorders.

Wilkinson's study reflects the increased general awareness of diversity of research participants' (socio)linguistic and communicative skills. Such awareness has a noticeable impact on methodological reflections, for example, regarding the way in which both typical and atypical linguistic proficiency in institutional and professional contexts is assessed. On the other hand, as pointed out by Jalkanen, cooperation between researchers of different disciplines and between researchers and practitioners is increasingly required. Further, instead of re-implementing the traditional asymmetry between researchers and research participants, contemporary research in applied linguistics seeks to explicitly acknowledge and emphasise the participants' role in the research process. The issues highlighted by Wilkinson and Jalkanen are explored further in the yearbook articles reviewed in sections 3 and 4 of this introduction.

While the need for methodological innovation and reflection is a constant requirement and driving force of scientific research, the ever-growing global mobility and digitalization of the past decade(s) have led to the occurrence of more and more wicked problems. Applied language studies, too, need new methodological tools or new ways of using already existing analytic tools and frameworks in order to tackle 
linguistic diversity, the growing awareness of societal asymmetries, and the increasing need for global equality and sustainability. By focusing on communication and language practices as a central locus of social processes, applied linguists are able to provide a detailed understanding of ongoing technological, educational, institutional, professional or participatory dynamics. The following sections will illustrate the challenges and methodological turning points we are facing in this domain, and sketch some of the ideas, tools and concepts for mastering them.

\section{Multimodal data, discourses and interaction in digi- tal and non-digital contexts}

Research on computer-mediated communication and online language (or digital discourse) provides an example of how the overall technological development has an effect on the type of data and observable phenomena (i.e. from textual and static output to increasingly multimedia and interactively generated output, see Herring 2019: 30-40) and how this ultimately leads to the development of more specific or even new methods. As the digital technologies and media landscape went from text-based, isolated applications to the integration and interconnection of various data types and modalities on online platforms (including also audio, video, or graphics such as emojis, photos or memes), an adaptation and update of analytic tools was made necessary. This can be illustrated by the development of ComputerMediated Discourse Analysis (CMDA) as initially coined by Herring (e.g. 1996, 2004), who suggested analysing each of the four levels of textual computer-mediated communication (i.e. structure, meaning, interaction management and social phenomena) with specific methods. This original "CMDA toolkit" (Herring 2019: 27) recommended various methods initially developed and used for analysing texts (e.g. text analysis, stylistics) or, to a limited extent, spoken discourse (e.g. interactional sociolinguistics, conversation analysis). In order to accommodate the growing complexity of digital platforms to the initial CMDA framework, Herring (2013) first proposed to add a fifth, multimodal level. However, as "multimodality" rather represents a basic feature of contemporary Computer-Mediated Communication (CMC) than a "linguistic level of analysis" (Herring 2019: 38), Herring suggested a reconceptualization of CMC as fundamentally being of multimodal nature. Within digital discourse research, and indeed in applied linguistics more generally, the notion of multimodality is understood and treated principally in two different but interrelated ways: on the one hand, it is considered the most pervasive characteristic of current digital discourse, on the other hand, it is employed as an analytic concept or framework. Although initially applied to visual elements that are to be found mostly offline (e.g. paintings, photos, public signs), the work by Kress and van Leeuwen on analysing visual design and, more specifically, on multimodal discourse (Kress \& van 
Leeuwen 1996, 2001) has been highly influential in digital discourse studies as well (see Jewitt 2016). Overall, a consensus has been reached "that text-based studies, the traditional focus of analysis, need to move forward by incorporating other modes of communication" (Garcés-Conejos Blitvich \& Bou-Franch 2019: 5).

In her contribution to this yearbook, Judit Háhn provides an example of how a multimodal approach can be applied to Facebook, a prototypical multimodal online platform that allows its users to use text, photos, graphics as well as pre-defined reactions (e.g. "likes") for interacting with each other. Within a course in English as a Foreign Language taking simultaneously place in a Finnish and a Czech university, the student participants were asked to establish a virtual exchange with their peers within a closed Facebook group. Interested in how the students construct their social presence when meeting online for the first time, Háhn investigates screenshots of these online threads by combining multimodal discourse analysis with the Community of Inquiry model of social presence and building on more recently proposed multimodal framework approaches to online interaction. She analyses the three social presence dimensions proposed by the Community of Inquiry model by considering the linguistic, visual and action modes of the students' postings and reactions, thereby developing an approach that can account for multimodal features of asynchronous digital communication and illustrating the impact of this type of virtual exchange for group cohesion and teamwork.

New technologies and media require us to rethink the whole research process, not only regarding the analytic tools, but also, more specifically, with respect to the ways in which we collect and approach our data. Instead of artificially treating online data as if they were being produced and consumed in a socio-material "vacuum" (Jones 2004), on- and offline practices are blending into each other, making it necessary to carefully reflect on the "where" and "what" of data collection (Bolander \& Locher 2020; Mayr \& Weller 2017). Consequently, not only one type of online data should be collected (e.g. one single entry point into the data); they ought to be complemented by other types of offline data to grasp the actual discursive practices in and meanings of online data. Researchers interested in digital discourse should thus seek to work with blended data sets (Bolander \& Locher 2020: 3), for example by complementing online or textual data with interviews, questionnaires, or ethnographic data that allow to better access and integrate the participants' knowledge, attitudes and perceptions (see, e.g. Salomaa 2019 on the use of Twitter during television-broadcasted sport events as an example for implementing this type of approach). As it might be unclear from the start which of the possible multiple entry points (or data types and ways to collect these) suit best the scope of a given study, digital discourse research should be designed as an exploratory process with flexible and redefinable boundaries (Bolander \& Locher 2020: 6-7).

The article by Esa Lehtinen and Elina Salomaa in this yearbook illustrates the use of multiple entry points to the data in order to grasp how on- and offline con- 
texts are entwined. In their study on digital discourses at the workplace, the authors propose to look at digital communication as part of a network of different communication practices that take place both on- and offline. The article underlines the need to analytically acknowledge both the variety of digital tools and more traditional, non-digital forms of communication, such as handwritten notes, in contemporary professional and organizational settings. Through text extracts and screenshots from a digital platform, a video-recorded meeting during which the same platform is used, ethnographic observations and interviews with the participants, Lehtinen and Salomaa show how the participants obtain important impulses from digital platforms for their offline work. Their study thus suggests that by considering multimedia organisational practices - rather than one specific digital practice only - research in applied linguistics can support an organisation in reflecting on a better and more efficient use of media and digital technologies for professional purposes.

The multiplicity and multitude of potential research material available today make it possible to shed new light also on phenomena that have long been of interest in applied linguistics. Researchers may draw on materials from a range of contexts, for example, to investigate real-life language use, common practices and discourses in different language communities, and diachronic or synchronic variation. The Common Language Resources and Technology Infrastructure (CLARIN), organized as a European Research Infrastructure Consortium (ERIC), was established in 2012 to provide researchers with access to large amounts of digital data as well as with tools to manage and analyse such data (e.g. Odijk 2016 and contributions to the special issue). The data available include, among others, textual and audio-visual L2 learner corpora, bilingual or multilingual parallel corpora and corpora of public and private computer-mediated communication, and various tools can be used, for example, to annotate or visualise the data or to run queries or concordances (see www.clarin.eu). For researchers engaged in applied language studies in Finland, the Language Bank of Finland, which is coordinated by the FIN-CLARIN consortium (www.kielipankki.fi/language-bank/), constitutes a valuable resource: researchers have carried out, for instance, corpus linguistics on learner Finnish, corpus-assisted discourse studies on online discussion forums or comparative analysis on video data of different language users (for overviews on data and related methods, see, e.g. Jantunen 2018; Jantunen \& Pirkola 2015; Kurki et al. 2019; Laippala 2019; Salonen et al. 2020; Salonen et al. 2019).

To counterbalance the quantity of data, applied linguists also draw on new technologies to enhance the quality of data. In their Big Video Manifesto, Mcllvenny and Davidsen (2017) call for "a re-sensing of video and audio", so that new recording technologies, powerful computing and extensive storage be used to their full potential also in qualitative studies of language and social interaction. That is, bearing in mind that they are never able to capture all-encompassing recordings of lived events, researchers should strive for using multiple cameras (incl. 360-degree) and 
microphones (incl. ambisonic) to collect data that they can continue to explore in depth from varying perspectives. What is more, Mcllvenny and Davidsen (2017; see also Mcllvenny 2018, 2020) develop tools for researchers to "inhabit the data": versatile video data can be imported into immersive virtual reality for conducting analysis individually or collaboratively (e.g. in CAVA360VR - Collaborate, Annotate, Visualise, Analysis 360 Video in Virtual Reality).

The quality of data may also be enhanced by complementing audio and video recordings with motion capture, eye-tracking and various physiological measurements. In their contribution to this yearbook, for example, Jarkko Niemi and Pilvi Heinonen relate the results of an automated analysis of a participant's facial expressions and galvanic skin response to the interactional, sequential context in which they occur, namely during a prospective customer's receipt of a salesperson's answer to a prior question in business-to-business telemarketing. Providing evidence from the analysis of an automated facial expression algorithm as well as a close sequential analysis, Niemi and Heinonen show that the customer treats the salesperson's answer as insufficient and that the two participants may in effect advance divergent trajectories of action in the telemarketing meeting. Niemi and Heinonen conclude that the different kinds of data, and the different means of analysing them, complement one another in ways that strengthen the reliability and effectiveness of the findings (see also, e.g. Kendrick 2017; Peräkylä et al. 2015; Stevanovic et al. 2017).

Again, the technological developments underway in applied linguistics can be seen to be part of a more general trend in research on human social activities, where appropriate methods are combined to investigate versatile sets of data. Working at these disciplinary interfaces requires that researchers have an understanding of both how to carry out automated analyses of quantitative data and how to conduct detailed work-intensive analyses of qualitative data. Whichever is their starting point, researchers need to be able to draw appropriate parallels between the different types of data and, moreover, remain critical of the analytic approaches that they adopt.

\section{Revisiting language proficiency: concepts and approaches}

When it comes to language learning and language proficiency, the above mentioned multidimensional, multi-layered - wicked - character of current challenges has become overt in the last one or two decade(s). Increasing awareness of diversity (or superdiversity, e.g. Arnault et al. 2016; Blommaert \& Rampton 2011) in society and the multiplicity of views on communication, language learning and language skills make it inevitable to reflect critically on common practices in teaching and assessing languages as well as in studying language learning and use. In her theore- 
tically-oriented article, Hannele Dufva addresses the importance of language proficiency from an individual and from a societal point of view. Language proficiency plays an important role in a person being able to participate in society, and knowing or not knowing language(s) (well enough) has an impact on everyone's lives in many ways. Thus, developing language proficiency does not only concern the individual learners and language teachers but has wider implications, and therefore critical reflection on prevailing concepts of language in general and language skills is important. The topicality of this issue is reflected in the broad range of papers approaching it from various angles at the AFinLA symposium as well as in this yearbook (see, in this volume, Halonen et al.; Intke-Hernandez; Männistö).

Dufva, who has been working extensively on these topics for many years, provides in her article an overview of the developments in applied language studies. The article could serve as an introductory article into theoretical concepts of language learning for language students or teachers in general. She stresses the need to finally overcome views that mental grammar is the basis of language learners'/ users' language skills and that they are static and abstract skills. Based on this, Dufva refers to the attempt to bridge the gap between cognitivist and social-interactive theories (e.g. Hulstijn et al. 2014) and develops further the ecological perspective (see, e.g. Kramsch 2002; Van Lier 2004) on language learning and proficiency looking at the actor and environment as a whole and focusing on embodiment, materiality and personal repertoire. She elaborates on multimodality as the central feature of a personal repertoire, considering variety and hybridity of the resources/affordances language learners and users draw on in different situations. Dufva's article opens also perspectives for future empirical research in the field of applied language studies as well as for practical approaches to language teaching and learning, focusing on linguistic actions rather than on languages as abstract, decontextualized systems. By giving some examples for research approaches at the end of the article, Dufva brings forward like many other authors on this yearbook the importance of developing new research methods as well as cooperating and interacting between different disciplines studying languages and language learning.

One example of such a multidisciplinary approach and a critical examination of standard practices in language assessment is provided by Mia Halonen, Ari Huhta, Sari Ahola, Tuija Hirvelä, Reeta Neittaanmäki, Sari Ohranen and Riikka Ullakonoja. The authors investigate whether the recognition of the test takers' L1 influences the assessment in a speaking test. In addition, they take a more thorough look on the effect of recognizing the test taker's "foreign accent" across the different assessment criteria, including pronunciation, fluency, and coherency, amongst others. The study presented in the article is part of a larger research project on the assessment of the speaking part of the National Certificates of Language Proficiency (the so-called YKI test), a high-stakes language proficiency test that serves as a societal gatekeeper. Proving B1 level (YKI 3) in this test is a requirement for applying 
for Finnish citizenship, and therefore impartiality in the assessment is of high importance. The focus groups in Halonen et al.'s study are L1 speakers of Thai, Estonian, Finland Swedish, Arabic, and Russian. The article presents well how the complexity of the research topic is mirrored in the multidisciplinary research approach, including researchers from different fields, such as sociolinguistics, (socio)phonetics, language testing, and statistics, and in the combination of several data collection and research methods. The analysis shows that the recognition of the test taker's L1 does influence the rating, but the effect is statistically significant only as regards the assessment criteria concerning pronunciation and fluency. Nevertheless, the impact of a single criterion had only a minor impact on the overall rating of the test taker's language proficiency. In addition to the results of the sub-study and the discussion of their implications, the authors provide insights into the research project as well as in data management and analysis.

In a similar vein, Henna Heinonen and Maria Kautonen introduce a new approach that provides much needed improvement in the teaching and assessment of L2 pronunciation. More specifically, they set out to establish criteria for describing $\mathrm{L} 2$ sentence stress to be used in the teaching and assessing of pronunciation. The data of their study consist of listener ratings of Finnish-speaking learners' pronunciation of Swedish. Heinonen and Kautonen planned the data collection together and have used it in two prior individual studies (Heinonen 2018; Kautonen 2018). In this article, they combine their efforts in cross-referencing some of their data categories in a new way. Heinonen and Kautonen systematically compare the numerical and verbal assessment of a learner to explore what kind of a sentence stress is perceived as successful and what kind of verbal descriptions are used of the highest and lowest ratings as well as of those in between. As the verbal descriptions of a desirable, successful sentence stress are often missing in curricula and learning objectives, it is important to try to establish a range of such descriptions. The model suggested by Heinonen and Kautonen may be implemented in creating verbal descriptions of various skill levels in pronunciation and such descriptions can further be implemented not only in teaching and assessment but also in research. Moreover, as sentence stress is a measurable feature, it is apparent that this approach could be applied in the development of electronic and automated assessment.

Providing a broader overview of the developments in the study of language proficiency via the notion of fluency, Pekka Lintunen, Maarit Mutta and Pauliina Peltonen shed light on the varied, somewhat vague, and partly overlapping use of the concept of fluency in the field of language learning and language teaching. Their review article traces the various methodological approaches that have been adopted in the study of fluency in Finland and elsewhere. Lintunen et al. draw on their co-edited volume (Lintunen et al. 2020a) that provides a collection of approaches to fluency in L2 learning and use, and they complement that work by providing an extensive review of the fluency studies conducted in Finland that take as their star- 
ting point explicitly defined measures or criteria in a specific language skill. Lintunen et al. show that while most of the Finnish fluency studies focus on oral skills and English as L2, some studies on Finnish as L1 (and L2) also exist. These studies make use of a wide variety of research approaches and perspectives with a great deal of versatility in participants. With regard to fluency in written language, Lintunen et al. show that the studies concentrating on L1 reading are well represented in Finnish research. They go on to identify and discuss the future avenues for fluency research, suggesting that it would be beneficial to adopt a more holistic approach to fluency by highlighting the connections between various subskills and that more attention should be given to fluency in connection to receptive skills as well as the multimodal dimension of interaction. Research should further endeavour to understand the role of fluency in new learning environments and technologically mediated interactions.

\section{$4 \quad$ Participatory research and the researcher's position}

In order to examine complex social issues at the intersection of the personal, the local, and the global as well as to adopt a critical agenda, applied linguists are increasingly turning to different types of participatory research approaches. Such approaches allow the research participants to have a more visible role in research not only in terms of making it possible to recognise their role in the generation of research data (see section 2 above), but also to acknowledge them as partners in research (Kuure, Riekki \& Keisanen 2013; McKinley 2020). This partnership can take different forms. For example, the nexus analytic research approach (Scollon \& Scollon 2004) adopted in Minna Intke-Hernandez's study guided the researcher to discuss the results of the research with her research participants, migrant mothers. Making the research participants aware of their already existing, well-functioning practices that they engage in in their everyday lives is one concrete means for the researcher to support the participants, in this case the migrant mothers in their progress towards empowerment and socialisation into the local language.

Indeed, participatory research approaches frequently aim at supporting or enabling the research participants' own activities in ways that contribute to their well-being, equality, or status in society (e.g. Groundwater-Smith et al. 2015; Hacker 2017) and often maintaining that research should engage in active and political change (e.g. Lovern \& Locust 2013; Mertens 2012; Tierney 1997). In this process, the reliability and validity, or trustworthiness of the chosen research design as well as research ethics need to be continuously considered because they need to be justified and discussed with various stakeholders. Marjut Männistö examines participants' experiences of inclusion during integration training for migrants in Finland and discovers that for these participants this consisted of experiences of having both autonomy and power as regards the activities during the working life 
period included in the training, and that communication skills play an important role in creating these experiences. While the hope for inclusion and integration may originate partly from outside, as societal aims, studies may also attempt to empower all the participants involved in research, as is the case in the study by Leena Kuure, Tiina Keisanen, Netta livari and Marianne Kinnula. This nexus analytic study originates in the work of a research group, the participants of which examine and reflect their own and the research participants' position in the nexus of practice, a Making project at school.

Activist research can take many forms, such as a linguistic landscape study (e.g. Abas \& Damico 2019; Ben Said \& Kasanga 2016). Sofie Henricson, combining qualitative and quantitative approaches to data, presents a pilot study of the unofficial layer of the urban linguistic landscape at two railway stations in Helsinki, and the discourses and ideologies encompassed therein. She first maps the linguistic landscapes of the activistic signs at the Helsinki Central Station, and then examines the change taking place at another station on the main line from Helsinki within the period of six months. The analysis of activistic linguistic landscapes also provokes the researcher to reflect on her position, role, and responsibilities as a researcher. Henricson recognises her role as a potentially active member in the studied linguistic landscape, such as getting involved in tearing or scraping the activistic signs and thus changing the landscape.

As is evident from above, in many forms of qualitative research the role of the researcher is changing from an objective and invisible mediator to an active participant in research. This is manifest also within individual research approaches, such as ethnography, which has broadened from the classical "fly on the wall" approach to a more interpretive one (Creswell \& Poth 2016; Koro-Ljungberg \& Greckhamer 2005). In terms of the articles in this yearbook, in Intke-Hernandez's study of migrant mothers'language socialisation, for example, the researcher was already an active member in the researched community when the study began, and the participants saw her as both a mother and a researcher. The researcher can thus take an active role as part of the researched community or study a community where they are already a member (see Kuure et al. this volume).

In addition to research conducted by single researchers, different kinds of collaborative projects are increasingly common. For example, Heinonen and Kautonen planned their data collection together, but conducted two separate research projects based on them. In this yearbook they approach their mutually collected data from a new angle by cross-referencing and comparing between verbal assessments and numeral ratings of a pronunciation task. Further, Kuure et al. conducted their research project as a shared ethnography: their research group focused on reflecting their own working processes, in relation to conducting a Making project at school as an interdisciplinary venture. They approach doing research not only as an activity but also as a community. Kuure et al. note that the collaboration of the 
research group has continued for more than a decade, making it possible for individual researchers to have varying roles and responsibilities in the research projects carried out. Consequently, continuous theoretical and methodological reflection on academic life, discipline-related differences and similarities, and the boundaries of academic communities, have been part of the group's work throughout the years. Such long-term trajectories also allow for deepening one's perspective and understanding of the changes taking place and the research process as a whole. The researcher's relationship with the community and the research topic itself may become personal, especially in long-term ethnography. Being able to see and assess long-term trajectories and changes in them also require longer timespans, varying from months to several years (see, in this volume, Henricson; Intke-Hernandez; Kuure et al.; and see also Räisänen \& Kankaanranta in press).

Koro-Ljunberg and Greckhamer (2005: 291) discuss the strategic turn of ethnography when describing the change from seeing culture as the object of research to addressing the complexities of aiming to produce, reproduce, and change the studied culture. This applies also to many other research approaches that lean towards transformative perspectives (Creswell \& Poth 2016). Choosing societal research topics, wanting to engage and contribute towards change, and participatory research all place different demands on the researcher and the chosen methodology. Pushing away from the role of the researcher as an objective observer towards an active participant is a choice that affects all aspects of the research process, from planning to reporting.

\section{Conclusion}

The previous sections have explored the theoretical and methodological challenges that applied language studies, among other disciplines, are currently facing. The complexity of language-related phenomena in everyday life, combined with the fast development of new technologies and platforms for participation, require agile adaptation and new research approaches. The current frameworks must be adapted, extended and combined in order to provide specific toolkits for addressing new methodological challenges. This also implies a strong trend towards multiple entry points into the chosen research field and towards an increasing use of multiple datasets. On the other hand, while research on traditional settings in applied language studies has profited from new digital tools for archiving, organising and analysing data, the use of digital and big data, or indeed, Big Video, also present new methodological challenges. These challenges concern, among others, the heterogeneous quality and thus reliability of the data as well as the need to develop new ethical guidelines with respect to the handling of until now possibly unknown and therefore new types of data (see, e.g. Williams et al. 2016). New types and multimodal formats 
of linguistic and other data require the development of adequate transcription systems and complex analytic skills (see Bolander \& Locher 2020: 6; Flewitt et al. 2012; Jewitt 2016), or specific knowledge related to the collection, coding, and handling of data and various datasets. Correspondingly, the analysis of data from new types of settings allows for the development of novel electronic and automated solutions. What is more, the multifaceted nature of language studies has brought forward a growing necessity to establish and exploit analytic concepts, frameworks and expertise across disciplinary boundaries. At the same time, research in applied language studies - like language studies in general - is experiencing a movement from a person-centred view of language repertoires and skills as well as of their assessment towards a participatory and multi-person view of social action. This new view applies not only to the design of the studies or the selection of research participants, but also to the dissemination and sharing of the findings.

Faced with global challenges such as the COVID-19 pandemic of 2020, which among other things postponed AFinLA's anniversary celebrations until later, we have to find ways of coping, adapting and again thriving as individuals, communities and societies. As the world changes, sometimes in dramatic ways, language use takes new forms and language-related phenomena evolve. For this reason, applied linguistics needs to constantly evolve and take on new methods to explore language in use - just as AFinLA has done for the past 50 years!

\section{References}

Abas, S. \& J. S. Damico 2019. The language of activism. Representations of social justice in a university space in Argentina. In N. Avineri, L. R. Graham, E. J. Johnson, R. C. Riner \& J. Rosa (eds) Language and social justice in practice. London: Routledge, 157-165.

Arnaut, K., J. Blommaert, B. Rampton \& M. Spotti 2016. Language and superdiversity. London: Routledge.

Ben Said, S. \& L. A. Kasanga 2016. The discourse of protest: frames of identity, intertextuality and interdiscursivity. In R. Blackwood, E. Lanza \& H. Woldemariam (eds) Negotiating and contesting identities in linguistic landscapes. London: Bloomsbury Academic, 71-83.

Blommaert, J. \& B. Rampton 2011. Language and superdiversity. Diversities, 13 (2), 1-21.

Bolander, B. \& M. Locher 2020. Beyond the online offline distinction: entry points to digital discourse. Discourse, Context \& Media, 35, 1-8.

Creswell, J. W. \& C. N. Poth 2016. Qualitative inquiry and research design: choosing among five approaches. London: SAGE Publications.

Duff, P. A. \& H. Byrnes (eds) 2019. SLA across disciplinary borders: new perspectives, critical questions, and research possibilities. Special issue. Modern Language Journal, 103, Supplement 2019.

Flewitt, R., R. Hampel, M. Hauck \& L. Lancaster 2012. What are multimodal data and transcription? In B. Dicks (ed.) Digital qualitative research methods, volume three: data analysis in digital applications. London: SAGE Publications, 57-76. 
Garcés-Conejos Blitvich, P. \& P. Bou-Franch 2019. Introduction to analyzing digital discourse: new insights and future directions. In P. Bou-Franch \& P. Garcés-Conejos Blitvich (eds) Analyzing digital discourse. New insights and future directions. London: Palgrave Macmillan, 3-22.

Groundwater-Smith, S., S. Dockett \& D. Bottrell 2015. Participatory research with children and young people. London: SAGE Publications.

Haapanen, L., L. Kääntä \& L. Lehti (eds) 2018. Diskurssintutkimuksen menetelmistä. On the methods in discourse studies. AFinLA-e. Soveltavan kielitieteen tutkimuksia 11 [AFinLA-e. Studies in Applied Linguistics 11]. Jyväskylä: Finnish Association of Applied Linguistics AFinLA.

Hacker, K. 2017. Community-based participatory research. London: SAGE Publications.

Herring, S. C. (ed.) 1996. Computer-mediated communication: linguistic, social and crosscultural perspectives. Amsterdam: John Benjamins.

Herring, S. C. 2004. Computer-mediated discourse analysis: an approach to researching online behavior. In S. A. Barab, R. Kling \& J. H. Gray (eds), Designing for virtual communities in the service of learning. New York: Cambridge University Press, 338-376.

Herring, S. C. 2013. Discourse in Web 2.0: familiar, reconfigured, and emergent. In D. Tannen \& A. M. Tester (eds) Georgetown University Round Table on languages and linguistics 2011: Discourse 2.0: language and new media. Washington, DC: Georgetown University Press, 1-25.

Herring, S. C. 2019. The coevolution of computer-mediated communication and computermediated discourse analysis. In P. Bou-Franch \& P. Garcés-Conejos Blitvich (eds) Analyzing digital discourse. New insights and future directions. London: Palgrave Macmillan, 25-68.

Hulstijn, J. H., R. F. Young, L. Ortega, M. Bigelow, R. DeKeyser, N. C. Ellis, J. Lantolf, A. Mackey \& S. Talmy 2014. Bridging the gap: cognitive and social approaches to research in second language learning and teaching. Studies in Second Language Acquisition, 36 (3), 368-421. https://doi.org/10.1017/S0272263114000035.

Irwin, T. \& G. Kossoff 2020. Wicked problems. Transition Design Seminar 2020. https://transitiondesignseminarcmu.net/classes-2/systems/\#1482254259729-27721fa6-4857 [accessed 1 Oct 2020].

Jantunen, J. 2018. Korpusavusteinen diskurssintutkimus (CADS): analyysiesimerkki homouden ja heterouden digitaalisista diskursseista [Corpus-assisted discourse studies (CADS): an analysis of digital discourses of homosexuality and heterosexuality]. In L. Haapanen, L. Kääntä \& L. Lehti (eds), Diskurssintutkimuksen menetelmistä. On the methods in discourse studies. AFinLA-e. Soveltavan kielitieteen tutkimuksia 11 [AFinLA-e. Studies in Applied Linguistics 11]. Jyväskylä: Finnish Association of Applied Linguistics AFinLA, 20-44. https://doi.org/10.30660/afinla.69259.

Jantunen, J. \& S. Pirkola 2015. Oppijansuomen sähköiset tutkimusaineistot. Nykytilanne [Digital corpora of learner Finnish. The status quo]. Virittäjä, 119 (1), 88-103. https://journal.fi/virittaja/article/view/46508.

Jewitt, C. 2016. Multimodal Analysis. In A. Georgakopoulou \& T. Spilioti (eds) The Routledge handbook of language and digital communication. London: Routledge, 69-83.

Jones, R. H. 2004. The problem of context in computer mediated communication. In P. LeVine \& R. Scollon (eds), Discourse and technology. Multi-modal discourse analysis. Washington, DC: Georgetown University Press, 20-33.

Kendrick, K. H. 2017. Using conversation analysis in the lab. Research on Language and Social Interaction, 50 (1), 1-11. https://doi.org/10.1080/08351813.2017.1267911. 
Koro-Ljungberg, M. \& T. Greckhamer 2005. Strategic turns labeled 'ethnography': from description to openly ideological production of cultures. Qualitative Research, 5 (3), 285-306. https://doi.org/10.1177/1468794105054456.

Kramsch, C. (ed.) 2002. Language acquisition and language socialization. Ecological perspectives. London: Continuum.

Kress, G. R. \& T. van Leeuwen 1996. Reading images: the grammar of visual design. London: Routledge.

Kress, G. R. \& T. van Leeuwen 2001. Multimodal discourse: the modes and media of contemporary communication. London: Arnold.

Kurki, T., N. Inaba, A. Kaivapalu, M. Koponen, V. Laippala, C. Leblay, J. Luutonen, M. Mutta, M. Nikulin, \& E. Reunanen 2019. Digilang - Turun yliopiston digitaalisia kieliaineistoja kehittämässä [Digilang - developing digital language resources of the University of Turku]. In J. Jantunen, S. Brunni, N. Kunnas, S. Palviainen \& K. Västi (eds), Proceedings of the Research Data and Humanities (RDHum) Conference 2019: data, methods and tools. Studia Humaniora Ouluensia 17. Oulu: University of Oulu, 41-56.

Kuure, L., T. Keisanen \& M. Riekki. 2013. Guiding towards genuine participation. In E. Christiansen, L. Kuure, A. Mørch \& B. Lindström (eds) Problem-based learning for the 21 st century. New practices and learning environments. Aalborg: Aalborg University Press, 259-281.

Laippala, V 2019. From bits and numbers to explanations - doing research on Internet-based big data. In J. Jantunen, S. Brunni, N. Kunnas, S. Palviainen \& K. Västi (eds) Proceedings of the Research Data and Humanities (RDHum) Conference 2019: data, methods and tools. Studia Humaniora Ouluensia 17. Oulu: University of Oulu, 139-157.

Lovern, L. L. \& C. Locust 2013. Native American communities on health and disability: borderland dialogues. New York, NY: Palgrave Macmillan.

Mcllvenny, P. 2020. New technology and tools to enhance collaborative video analysis in live 'data sessions'. SocArXiv. https://doi.org/10.31235/osf.io/eu7yw.

Mcllvenny, P. 2018. Inhabiting spatial video and audio data: towards a scenographic turn in the analysis of social interaction. Social Interaction. Video-Based Studies of Human Sociality, 2 (1). https://doi.org/10.7146/si.v2i1.110409.

Mcllvenny, P. \& J. Davidsen 2017. A Big Video Manifesto. Re-sensing video and audio. Nordicom-Information, 39 (2), 15-21. https://www.nordicom.gu.se/sites/default/files/kapitel-pdf/mcilvenny_davidsen.pdf.

McKinley, J. (2020). Introduction: theorizing research methods in the 'golden age' of applied linguistics research. In J. McKinley \& H. Rose (eds) The Routledge handbook of research methods in applied linguistics. New York: Routledge, 107-124.

Mertens, D. M. 2012. Transformative mixed methods: addressing inequities. American Behavioral Scientist, 56 (6), 802-813.

Mayr, P. \& K. Weller 2017. Think before you collect: setting up a data collection approach for social media studies. In L. Sloan \& A. Quan-Haase (eds) The Sage handbook of social media research methods. London: SAGE Publications, 107-124.

Odijk, J. 2016. Introduction: linguistic research using CLARIN. Lingua, 178, special issue on "linguistic research in the CLARIN infrastructure", 1-4. https://doi.org/10.1016/j.lingua.2016.04.003.

Peräkylä, A., P. Henttonen, L. Voutilainen, M. Kahri, M. Stevanovic, M. Sams \& N. Ravaja 2015 Sharing the emotional load: recipient affiliation calms down the storyteller. Social Psychology Quarterly, 78 (4), 301-323. https://doi.org/10.1177/0190272515611054.

Quan-Haase, A. \& L. Sloan 2017. Introduction to the handbook of social media research methods: goals, challenges and innovations. In L. Sloan \& A. Quan-Haase (eds) The Sage handbook of social media research methods. London: SAGE Publications, 1-9. 


\section{xvi METHODOLOGICAL TURNS IN APPLIED LANGUAGE STUDIES}

Räisänen, T. \& A. Kankaanranta in press. The use of English as corporate language in global knowledge work over a 15-year business career. European Journal of International Management. https://doi.org/10.1504/EJIM.2020.10028833.

Salomaa, E. 2019. Television ja Twitterin risteyksessä: Sosiaalinen televisio vuorovaikutuksen ja mediatapahtumaan osallistumisen välineenä [In the intersection of television and Twitter: Social television as a tool for interaction and participation in a media event]. JYU Dissertations 140. Jyväskylä: University of Jyväskylä. https://jyx.jyu.fi/handle/123456789/65878\#.

Salonen, J., A. Kronqvist \& T. Jantunen 2020. The Corpus of Finnish Sign Language. In E. Efthimiou, F. Stavroula-Evita, T. Hanke, J. A. Hochgesang, J. Kristoffersen \& J. Mesch (eds) Proceedings of the 9th Workshop on the Representation and Processing of Sign Languages: sign language resources in the service of the language community, technological challenges and application perspectives. Paris: European Language Resources Association (ELRA), 197-202. http://www.Irec-conf.org/proceedings/lrec2020/workshops/SIGN2020/index.html.

Salonen, J., A. Puupponen, R. Takkinen \& T. Jantunen 2019. Suomen viittomakielten korpusta rakentamassa [Building Corpus FinSL]. In J. Jantunen, S. Brunni, N. Kunnas, S. Palviainen \& K. Västi (eds) Proceedings of the Research Data and Humanities (RDHum) Conference 2019: data, methods and tools. Studia Humaniora Ouluensia 17. Oulu: University of Oulu, 81-96.

Scollon, R. \& S. W. Scollon 2004. Nexus analysis: discourse and the emerging Internet. London: Routledge.

Stevanovic, M, T. Himberg, M. Niinisalo, M. Kahri, A. Peräkylä, M. Sams \& R. Hari 2017. Sequentiality, mutual visibility, and behavioral matching: body sway and pitch register during joint decision making. Research on Language and Social Interaction, 50 (1), 33-53. https://doi.org/10.1080/08351813.2017.1262130.

Tierney, W. G. 1997. Academic outlaws: queer theory and cultural studies in the academy. Thousand Oaks, CA: SAGE Publications.

van Lier, L. 2004. The ecology and semiotics of language learning. A sociocultural perspective. Boston: Kluwer Academic Publishers.

Williams, M., P. Burnap \& L. Sloan 2016. Crime sensing with big data: the affordances and limitations of using open-source communications to estimate crime patterns. British Journal of Criminology, 57 (2), 320-340. https://doi.org/10.1093/bjc/azw031. 